\title{
IMPLEMENTASI MODEL PEMBELAJARAN INKUIRI UNTUK MENINGKATKAN AKTIVITAS BELAJAR SISWA PADA MATA PELAJARAN KIMIA
}

\author{
Istiqomah Fenica1 ${ }^{*}$, I Wayan Muderawan², Putu Widiartini ${ }^{3}$ \\ 1 Universitas Pendidikan Ganesha \\ 2Universitas Pendidikan Ganesha \\ ${ }^{3}$ SMA Negeri 1 Singaraja
}

\begin{abstract}
Abstrak
Penelitian ini bertujuan untuk meningkatkan aktivitas belajar siswa kelas XI MIA 6 SMA N 1 Singaraja tahun ajaran 2016/2017 pada mata pelajaran kimia dengan penerapan model pembelajaran inkuri terbimbing. Penelitian ini merupakan penelitian tindakan kelas yang dilaksanakan dalam dua siklus. Setiap siklus terdiri dari tahap perencanaan tindakan, pelaksanaan tindakan, observasi/evaluasi dan refleksi. Subjek penelitian ini adalah siswa kelas XI MIA 6 SMA N 1 Singaraja dengan jumlah 30 siswa, objek penelitian meliputi model pembelajaran inkuiri terbimbing, dan aktivitas belajar siswa. Materi pokok penelitian ini adalah laju reaksi yang terdiri dari dua kompetensi dasar yaitu tentang teori tumbukan, faktor-faktor laju reaksi, penentuan orde reaksi dan persamaan laju reaksi.

Hasil penelitian ini menunjukkan bahwa melalui penerapan model pembelajaran inkuiri terbimbing dapat meningkatkan aktivitas belajar siswa dimana pada siklus 1 aktivitas belajar siswa dengan kriteria baik meningkat dari $43,33 \%$ menjadi $46.67 \%$ begitu juga dengan kritesisa sangat baik meningkat dari $26,67 \%$ menjadi $43,33 \%$ seiring turunnya aktivitas siswa yang kurang baik dari $30 \%$ menjadi $10 \%$. Berdasarkan analisis data dan pembahasan disimpulkan bahwa aktivitas belajar siswa pada materi laju reaki dapat meningkat dengan penerapan model Inkuiri terbimbing.
\end{abstract}

Kata-kata kunci:

Model pembelajran inkuiri terbimbing dan Aktivitas belajar

\section{Pendahuluan}

Salah satu mata pelajaran yang wajib bagi siswa SMA jurusan Ilmu Pengetahuan Alam (IPA) adalah pelajaran kimia. Mata pelajaran kimia menjadi sangat penting dalam masyarakat karena dalam keseharian kita akan selalu berinteraksi dengan zat kimia. Sehingga diperlukan metode maupun pendekatan yang tepat dalam menjelaskan materi kimia agar tidak menimbulkan salah konsep untuk beberapa materi yang memang sulit dipahami. Sebagian besar objek yang dipelajari dalam ilmu kimia berisi konsep-konsep dan rumus yang mendukung konsep-konsep tersebut. salah satu hal yang unik dan pehatikan adalah bahwa materi yang diajarkan kebanyakan bersifat abstrak. Oleh karena itu siswa harus mulai mengembang imajinasi agar dapat memahami konsep yang mendasar dalam ilmu kimia.

Pada mata pelajaran kimia, setiap konsep abstrak yang baru difahami siswa perlu segera diberi penguatan agar mengendap dan bertahan lama dalam memori siswa, sehingga akan melekat dalam pola fikir dan pola tindakannya. Untuk itulah, maka diperlukan adanya pembelajaran melalui perbuatan dan pengertian, tidak hanya sekedar hafalan atau mengingat saja karena hal ini akan mudah dilupakan oleh siswa. Pembelajaran yang dilakukan dengan bantuan media akan memberikan kesan tersendiri serta pengalaman baru untuk siswa, sehingga materi akan mudah di pahami.

Menurut Arifin (1995: 222), beberapa kesulitan siswa dalam mempelajari ilmu kimia dapat bersumber pada: (1) kesulitan dalam memahami konsep-konsep dalam ilmu kimia maupun materi kimia secara keseluruhan merupakan konsep atau materi yang abstrak dan kompleks sehingga untuk mengatasi hal tersebut konsep perlu ditunjukkan dalam bentuk yang lebih konkret, misalnya dengan percobaan atau media tertentu, (2) kesulitan dengan angka. Sering dijumpai siswa yang kurang memahami rumusan perhitungan kimia, hal ini disebabkan karena siswa tidak mengetahui dasar-dasar 
matematika dengan baik.

Berdasarkan hasil wawancara melalui angket yang telah dilakukan pada taggal 2 September 2017 diketahui bahwa siswa masih merasa pelajaran kimia tergolong pelajaran yang susah di pahami karena sebagian besar bersifat abstrak, tidak bisa di banyangkan sehingga sulit di mengerti. Selain itu banyaknya perhitungan yang rumit dan rumus-rumus yang sulit dipahami menjadi salah satu hal yang membuat siswa menjadi sulit dalam memahami konsep.

Berdasarkan pengamatan proses belajar mengajar di kelas masih ada siswa yang sibuk dan bercerita dengan teman saat pelajaran kiimia bahkan ada yang mengantuk dan merasa bosan. Saat guru memberikan kesempatan untuk bertanya hal yang kurang dipahami, siswa masih terlihat malu-malu untuk bertanya. Begitu juga saat diberikan kesempatan untuk menjajwab pertanyaan atau maju mempresentasikan hasil diskusi siswa masih saling menunjuk teman lain. Disaat guru memberikan kesempatan kepada siswa untuk mengajukan pertanyaan terkaiat materi yang dirasa sulit siswa masih bermalasmalasan untuk bertanya, dan ketika guru memberi kesempatan untuk mengutarakan pendapat atau menjawab pertanyaan yang sedang di diskusikan hanya beberapa siswa yang aktif menjawab. Saat diskusi berlangsung hanya beberapa siswa yang mengerjakan tugas sedangkan beberapa anggota kelompok tidak ikut andil dalam menyelesaikan tugas. Hal ini menunjukkan masih rendahnya aktivitas belajar siswa pada pelajaran kimia. Rendahnya aktivitas belajar siswa berpengaruh pada ppengetahuan yang didapatkan oleh siswa sehingga secara tidak lamgsung akan berdampak pada hasil belajar siswa yang rendah pula.

Siswa dituntut untuk dapat menguasai kompetensi tertentu melalui proses pembelajaran baik secara indivisual maupun interaksi dengan temannya agar dapat mencapai Kriteria Ketuntasan Minimal (KKM) untuk setiap kompetensi dasar yaitu 80 untuk kelas XI MIA. Kenyataanya siswa masih banyak yang belum mencapai KKM. Berdasarkan hasil Ulangan pada bab termokimia diketahui bahwa kelas XI MIA 6 memiliki tingkat ketuntasan paling rendah dibanding kelas yang lainnya yaitu sebesar $33,3 \%$, sehingga perlu diadakan penelitian tindakan kelas yang bertujuan untuk meningkatkan minat dan prestasi belajar siswa.

Berbagai permasalahan yang sudah diutarakan sebelumnya akan dipecahkan dengan adanya Penelitian Tindakan Kelas (PTK) atau Classroom Action Rasearch (CAR) yang bertujuan untuk memperbaiki dan meningkatkan kualitas pembelajaran (Suyadi, 2012: 6). Dalam penelitian tindakkan kelas, peneliti dan guru dapat melakukan penelitian terhadap siswa dilihat dari segi aspek interaksinya dalam proses pembelajaran. Peneliti dan guru secara refleksi dapat menganalisis dan mensintesis terhadap apa yang dilakukan di kelas. Dalam hal ini berarti dengan melakukan penelitian tindakan kelas, pendidik dapat memperbaiki praktik pembelajaran sehingga menjadi lebih efektif (Suwandi, 2008: 12).

Penggunaan pembelajaran inkuiri terbimbing, dapat meningkatkan pemahaman siswa dengan melibatkan siswa dalam kegiatan praktikum secara aktif, sehingga konsep yang dicapai lebih baik dan memberikan dampak positif terhadap hasil belajar dan aktivitas belajar (Suminten, 2015). Penggunaan model pembelajaran inkuiri terbimbing diharapkan dapat melatih siswa disiplin dan meningkatkan pemahaman dalam pelajaran kimia, serta mampu meningkatkan keaktifan siswa dalam kegiatan belajar.

Berdasarkan penelitian yang dilakukan Sutriana Jabir (2015) penerapan model pembelajaran Inkuri terbimbing dapat meningkatkan hasil belajar kimia pada aspek pengetahuan siswa Kelas XI MIA 2 SMA N 4 Singgaraja dengan peningkatan nilai rata-rata siswa sebesar $4.28 \%$ dan peningkatan ketuntasan siswa $12.82 \%$. Begitu juga dengan penelitian yang dilakukan oleh Hidayah (2015) penerapan model pembelajaran Inkuri terbimbing disertai LKS pada materi hidrolisis garam dapat meningkatkan aktivitas belajar siswa kelas X MIA C di SMA N 1 Kebumen pada semester 2 tahun pelajaran 2013/2014. Hasil lebih rinci mengenaik kenaikan aktivitas belajar dapat di lihat dari peningkatan aktivitas visual sebesar $36,58 \%$, aktivitas oral sebesar $20,06 \%$, aktivitas mendengarkan sebesar $10,19 \%$ serta aktivitas menulis sebesar 2,32\%.

\section{Metode}

Penelitian ini merupakan Penelitian Tindakan Kelas (PTK) atau Classroom Action Research dengan menerapkan Model Pembelajaran Inkuiri, yang secara umum bertujuan untuk meningkatkan aktivitas dan hasil belajar pada materi kimia. Subjek pada penelitian ini adalah siswa kelas XI MIA 6 semester ganjil SMA Negeri 1 Singaraja tahun ajaran 2016/ 2017, dengan jumlah siswa sebanyak 30 orang yang terdiri dari 12 siswa laki-laki dan 18 siswa perempuan. Pemilihan subyek dalam penelitian ini didasarkan pada pertimbangan bahwa subyek tersebut mempunyai permasalahan-permasalahan yang telah teridentifikasi pada saat observasi dan wawancara dengan guru serta siswa salah 
satunya yaitu hasil belajar siswa terhadap mata pelajaran kimia pokok bahaan termokimia rendah dengan Kriteria ketuntasan minimal 80 namun siswa yang tuntas hanya $33.3 \%$. Penggunaan model pembelajaran yang telah dirancang diharapkan tepat diterapkan pada siswa kelas XI MIA 6 semester ganjil SMA Negeri 1 Singaraja. Objek penelitian ini adalah proses pembelajaran dan hasil belajar siswa. Proses disini yang dimaksud adalah aktivitas belajar yang meliputi oral activities, visual activities, learning activities dan writing activities. Sedangkan hasil belajar yang dimaksud adalah hasil belajar siswa yang meliputi aspek kognitif, dan aspek afektif.

Penelitian tindakan kelas yang dilakukan ini mengikuti model yang dikembangkan oleh Kemmis dan Mc Taggart dalam Kasbolah (2001: 63-65) yaitu berupa model spiral. Perencanaan Kemmis menggunakan sistem spiral reflektif diri yang dimulai dengan rencana tindakan (planning), tindakan (acting), pengamatan (observing), dan refleksi (reflecting). Menurut Arikunto (2009:117), kegiatan ini disebut dengan satu siklus kegiatan pemecahan masalah. Apabila satu siklus belum menunjukkan tanda-tanda perubahan ke arah perbaikan (peningkatan mutu), kegiatan riset dilanjutkan pada sikus kedua dan seterusnya. Namun jika terget tercapai pada siklus I penelitian dapat di hentikan.

Sumber data yang digunakan pada penelitian ini adalah informan, yaitu guru dan siswa. Selain itu juga berasal dari peristiwa atau perilaku yang dialami siswa selama melaksanakan kegiatan pembelajaran di kelas, serta dokumen atau arsip dan hasil tes. Teknik pengumpulan data utama yang digunakan dalam penelitian ini dilakukan dengan dua teknik yakni tes dan non tes. Tes disusun dan dilakukan untuk mengetahui tingkat kemampuan kognitif siswa sesuai dengan siklus yang ada. Tes dilaksanakan pada akhir siklus I dan siklus II, hal ini bertujuan untuk mengetahui implikasi dari tindakan yang telah diberikan dalam proses pembelajaran terhadap penguasaan konsep materi dan hasil belajar siswa pada materi kimia.

Analisis dalam Penelitian Tindakan Kelas dimulai setelah berakhirnya siklus I. Datadata dari hasil penelitian di lapangan diolah dan dianalisis secara kualitatif. Analisis kualitatif yang dimaksud yaitu analisis deskriptif, setiap indikator dalam soal dihitung persentasenya seberapa banyak siswa menjawab benar kemudian dideskripsikan. Analisis deskriptis kualitatif memberikan gambaran sejelasjelasnya tentang proses dan pelaksanaan pembelajaran, serta berhubungan dengan hasil belajar siswa. Teknik analisis kualitatif mengacu pada model analisis Miles dan Huberman (1995: 16-19) yang dilakukan dalam tiga komponen yaitu 1) reduksi data, 2) penyajian data dan 3) penarikan kesimpulan dan verifikasi. Pada penelitian ini indikator keberhasilannya meliputi peningkatan aktivitas dan prestasi belajar siswa yang berupa hasil belajar.

\section{Hasil}

$\begin{array}{ccc}\text { Pada } & \text { pelaksanaan tindakan siklus I } \\ \text { peneliti } & \text { menerapkan } & \text { pembelajaran }\end{array}$ menggunakan model inkuiri terbimbing dengan sintaks yang terdapat dalam RPP. Pada awal kegiatan peneliti menyampaikan kepada siswa bahwa kegiatan pembelajaran kimia pada pokok bahasa laju reaksi akan dilaksanakan dengan menerapkan model pembelajaran inkuiri terbimbing. Langkah-langkah dalam pembelajaran inkuri terbiming yaitu : 1) orientasi, 2) merumusan masalah, 3) mengajuan hipotesis, 4) mengumpulkan data, 5) menguji data dan 6) merumuskan kesimpulan. Metode yang digunakan selama model pembelajaran inkuiri terbimbing adalah eksperimen, diskusi kelompok dan tanya jawab interaktif. Oleh karena itu dibentuk kelompok-kelompok belajar yang terdiri atas 5 kelompok yang masingmasing terdiri dari 6 orang. Proses pelaksanaan pembelejaran dilakukan sesui dengan tahapantahapan pada model inkuiri terbimbing. Berikut dipaparkan lebih Lanjut deskripsi proses pembelajaran.

Siklus I terdiri dari satu kali pertemuan dimana pada saat pembelajaaran berlangsung guru melakukan observasi terhadap aktivitas siswa didalam kelas dan pada akhir pertemuan guru memberikan angket terkait aktivitas belajar serta angket respon siswa terhadap pembelajaran yang telah dilaksanakan. Siklus I membahas materi tentang teori tumbukan yang dibagi menjadi tumbukan efektif dan tidak efektif, hubungan teori tumbukan dengan laju reaksi dan konsep laju reaksi. Keagiatan pendahuluan dilakukan diawali dengan salam pembuka, mengabsen kehadiran siswa dan semua siswa hadir dan mengikuti pembelajaran. Selanjutnya guru memberikan apersepsi mengenai ciri-ciri reaksi kimia selanjutnya guru memberikan motivasi dengan mendemosntrasikan penyalaan korek kayu yang ditumbukan dengan wadahnya dengan pelan sehingga tidak terjadi nyala api dan dengan keras sehingga menyalakan api. Setelah itu guru menyampaikan tujuan pembelajaran pada pertemuan itu. Kemidian guru memberikan LKS kepada setiap kelompok yang sudah di bentuk sebelumnya. Pada tahap orientasi guru membeimbing siswa untuk mencermati vidio 
yang ditayangkan, selanjutnya siswa menuliskan informasi-informasi yang diperoleh, merumuskan masalah serta membuat hipotesis dari permasalah yang telah di tuliskan. Selanjutnya siswa diberi kesempatan untuk mengumpulkan data melalui studi literasi. Lalu menguji data dengan menyelesaikan Lembar Kerja Siswa secara berkelompok. Selanjutnya memberikana kesempatan kapada perwakilan kelompok untuk mempresentasikan hasil diskusinya Pada tahap ini terdapat 10 siswa yang aktif mempresentasikan hasil diskusi secara individu mapun bertanya terkait materi yang belum jelas, namun juga ada sekelompok anak yang duduk dibelakang yang bercanda dengan teman. Disela-sela kegiatan siswa menjawab pertanyaan terdapat siswa yang meminta waktu untuk mecatat jawaban dari pertanyaan yang sudah dikoreksi. Guru meluruskan pemahaman siswa yang belum sesuai serta memberikan penguatan pada materi dan konsep yang dianggap penting Selanjunya guru membimbing siswa untuk merumuskan kesimpulan dari pembelajaran yang telah dilakukan. Diakhir pembelajaran guru memberikan tugas kepada siswa untuk membuat ringkasan dari materi yang dipelajari hari itu dengan waktu pengerjaan 10 menit. Setelah itu guru memberikan angket terkait aktivitas belajar siswa sembari memberitahukan materi pelajaran pada pertemuan selanjutnya yaitu tentang faktor-faktor laju reaksi yang akan dilaksanakan dengan metode praktikum.

Selama proses pembelajaran penelitia membuat catatan lapangan (lembar onservasi) mengenai hal-hal penting pada pelaksanaan pembelajaran diantaranya: a) hanya beberapa siswa saja yang aktif berdiskusi dalam kelompok, b) siswa lain cenderung pasif dan menyerahkan tugas menyelesaikan LKS kepada teman yang mereka anggap lebih mampu, meskipun pembelajaran berjalan lancar namun hanya beberapa siswa yang terlibat aktif, c) beberapa siswa belum paham dengan pertanyaan yang terdapat pada LKS sehinnga butuh waktu lebih untuk menjelaskan kembali maksud dari pertanyaan di LKS.

Siklus II terdiri dari dua pertemuan dimana pertemuan pertama membahas materi terkait faktor-faktor yang mempengaruhi laju reaksi sedangkat pada pertemuan kedua membahas materi tentang penentuan orde dan penulisan persamaan laju reaksi. Kegiatan pembelajaran pada pertemuan pertama siswa melakukan kegiatan praktikum mengenai faktorfaktor laju reaksi berbasis green chemistry, dimana bahan yang digunakan merupakan bahan-bahan yang ramah lingkungan dan aman. Kegiatan pembelajaran dilakukan di laboratorium diawali dengan mengucapkan salam dari siswa kepada guru lalu guru mengabsen kehadiran siswa dimana siswa sudah duduk berdasarkan kelompok masing-masing. Guru memberikan contoh aplikasi faktor-faktor laju reaksi pada kehidupan sehari-hari seperti penyimpanan bahan makanan mentah di dalam kulkas, memotong tempe dengan ukuran kecil kecil saaat di goreng lebih cepat matang dari pada tempe yang dogoreng dengan potongan yang lebih besar serta sedikit pengetahuan tambahan mengenai green chemistry sebagai motivasi. Selanjutnya guru memberikan apersepsi dengan menanyakan kembali mengenai materi laju reaksi. Setelah itu siswa dipersilahkan untuk mencermati LKS terkait dengan percobaan. Guru mengarahkan siswa untuk merumuskan masalah setelah itu menyusun hipotesis dan menuntun siswa dalam memilih alat dan bahan yang akan digunakan dalam percobaan sesuai dengan cara kerja yang sudah diberikan dalam LKS.

Selanjutnya siswa melakukan percobaan mengenai faktor-faktor laju reaksi meliputi pengaruh luas permukaan dan konsentrasi (menggunakan jezzcol), katalis (menggunakan hati ayam), suhu (menggunakan larutan kanji, larutan vitamin $\mathrm{C}$, larutan betadin serta peroksida dan air) terhadap laju reaksi. Pada tahap mengumpulkan data siswa melakukan percobaan sesui dengan langkahlangkah yang ada di LKS, setiap siswa dalam kelompok terlibat aktif dalam melakukan percobaan. Guru mengawasi dan membimbing siswa ketika siswa mengalami kebingungan dalam langkah kerja. Setelah selesai melakukan percobaan, siswa mencatat hasil percobaan dan menganalisis data yang sudah diperoleh serta menguji data dengan melengkapi pertanyaan yang ada di LKS.

Kegiatan pembelajaran pertemuan kedua ada siklus II siswa melakukan percobaan untuk menentukan orde reaksi. Kegiatan yang dilakukan di lab diawali dengan mengucapkan salam, guru mengabsen kehadiran siswa lalu dilanjutkan memberikan apersensi terkait materi sebelummnya yaitu faktor-faktor laju reaksi. Sebelum melakukan percobaan guru membimbing siswa dalam merumuskan masalah serta merumuskan hipotesis dari rumusan masalah yang telah dibuat. Setelah itu siswa mengumpulkan data dengan melakukan percobaan sesaui dengan langkah-langkah yang ada di LKS. Setelah memperoleh data percobaan, siswa mengolah data sesaui dengan petunjuk LKS serta menjawab pertanyaan yang ada di LKS. Guru memberikan kesempatan kepada perwakilan kelompok untuk mempresentasikan hasil diskusinya. Setelah itu guru memberikan 
penguatan pada konsep-konsep yang diaggap penting serta membimbing siswa untuk menyimpulkan hasil kegiatan pembelajaran yang telah dilakukan.

Tabel 1. Hasil Observasi Kegiatan Siswa Kelas XI MIA 6 SMA N 1 Singaraja Tahun Pelajaran 2016/2017 Saat Belajar Mengajar.

\begin{tabular}{lccc}
\hline \multicolumn{1}{c}{ Observasi } & \multicolumn{3}{c}{ Siklus/Pertemuan } \\
& I & II & \\
& 1 & 2 & 3 \\
\hline Ada siswa yang tidak masuk kelas. & 0 & 0 & 0 \\
Ada siswa yang terlambat masuk kelas. & 0 & 0 & 0 \\
Ada siswa yang tidak membawa buku kimia. & 0 & 0 & 0 \\
Ada siswa masih belajar materi pelajaran lain sewaktu guru mengajar. & 2 & 0 & 0 \\
Ada siswa yang mengerjakan PR atau tugas sewaktu guru mengajar. & 0 & 0 & 0 \\
Ada siswa yang tidak mengerjakan PR atau tugas. & 0 & 0 & 0 \\
Ada siswa yang bertanya mengenai materi pelajaran. & 2 & 2 & 3 \\
Ada siswa yang tidak memperhatikan sewaktu guru menerangkan. & 2 & 1 & 0 \\
Ada siswa yang mengerjakan soal latihan di papan tulis. & 4 & 3 & 7 \\
Ada siswa yang menjawab pertanyaan guru tanpa ditunjuk. & 1 & 2 & 4 \\
Ada siswa yang berbincang dengan teman waktu pelajaran & 3 & 0 & 0 \\
berlangsung. & & & \\
Ada siswa yang mengikuti pelajaran sambil tiduran. & 1 & 0 & 0 \\
Ada siswa yang mencontek ketika diberi tugas individu & 0 & 0 & 0 \\
\hline
\end{tabular}

\section{Pembahasan}

Berdasarkan penelitian yang sudah dilakukan, penerapan model pembelajaran inkuiri terbimbing dapat meningkatkan aktivitas belajar siswa pada materi laju reaksi lebih spesifiknya pada kompetensi dasar memahami teori tumbukan serta menganalisis faktor-faktor yang mempengaruuhi laju reaksi dan menentukan orde berdasarkan hasil percobaan. Selain diterapkan pada materi laju reaksi peneliti optimis model inkuiri dapat diteapkan juga pada materi lain, karena pada materi laku reaksi sudah memakili meteri kimia yang berupa konsep, percobaan dan perhitungan.

Hasil dari penelitian ini menunjukkan bahwa ppenerapan model pembelajaran inkuiri terbimbing dapat meningkatkan aktivitas belajar siswa. Hal tersebut karena dengan penemuan masalah sampai penyelesaian masalah semua dilakukan oleh siswa dengan bimbingan guru. Dengan demikian siswa menemukan jawaban sendiri atas permasalah yang dihadapi akan meningkatkan aktivitas belajar siswa secara tidak langsung dapat merubah anggapan bahwa kimia sulit dipelajari. Berdasarkan hasil analisis angket aktivitas belajar siswa diketahui adanya peningkatan pada siklus II, hal tersebut karena pada siklus II menemukan jawaban dari permasalahan yang dipecahkan melalui percobaan. Secara tidak langsung setiap siswa dituntut untuk aktif dalam pembelajaran, serta terlibat langsung dalam diskusi kelompok. Selain itu siswa sudah mulai menyadari pentingnya kerja sama kelompok, sehingga siswa-siswa yang lebih memahami telah mangajari anggota lain sebaik mungkin sehingga semua anggota kelompok memahami materi secara merata.

Dampak dari penerapa model pelbelajaran inkuiri secara tidak langsung telah meningkatkan hasil belajar aspek pengetahuan siswa yang ditunjukkan oleh meningkatnya persentase ketuntasan siswa sebelum penerapan model yaitu $33,3 \%$ pada materi termokimia menjadi $90 \%$ pada laju reaksi (akhir siklus II). Keberhasilan penetilian tindakan kelas dapat dilihat dari tercapainya target yang telah ditetapkan atau indikator penelitian. Indikator penelitian ini didasarkan kesepakatan peneliti dengan guru pamong melihat keadaan sebelum diberikan perlakuan.ketercapaian indikator penelitian pada tiap siklus dapat dilihat pada tabel berikut:

Tabel 2. Ketercapaian Indikator Siklus I dan Siklus II

\begin{tabular}{|c|c|c|c|c|c|}
\hline \multirow[t]{2}{*}{ Aspek } & \multirow[t]{2}{*}{ Indikator } & \multicolumn{2}{|c|}{ Target } & \multicolumn{2}{|c|}{ Pencapaian } \\
\hline & & Siklus I & Siklus II & Siklus I & Siklus II \\
\hline $\begin{array}{l}\text { Visual } \\
\text { activities }\end{array}$ & $\begin{array}{l}\text { Siswa memberikan perhatian } \\
\text { selama guru menerangkan konsep. }\end{array}$ & $50 \%$ & $65 \%$ & $74,6 \%$ & $75 \%$ \\
\hline
\end{tabular}




\begin{tabular}{|c|c|c|c|c|c|}
\hline $\begin{array}{l}\text { (Sardiman, } \\
\text { 2010: 101). }\end{array}$ & $\begin{array}{l}\text { Siswa memberikan perhatian } \\
\text { selama diskusi kelompok. }\end{array}$ & $50 \%$ & $60 \%$ & $76,3 \%$ & $76,7 \%$ \\
\hline \multirow[t]{2}{*}{$\begin{array}{l}\text { Oral activities } \\
\text { (Sardiman, } \\
\text { 2010: 101). }\end{array}$} & $\begin{array}{l}\text { Siswa aktif berdiskusi untuk } \\
\text { memecahkan masalah yang } \\
\text { diberikan guru. }\end{array}$ & $50 \%$ & $65 \%$ & $84,6 \%$ & $83,9 \%$ \\
\hline & $\begin{array}{l}\text { Siswa bertanya pada guru jika ada } \\
\text { hal yang belum jelas }\end{array}$ & $50 \%$ & $60 \%$ & $82,5 \%$ & $85,4 \%$ \\
\hline $\begin{array}{l}\text { Listening } \\
\text { activities }\end{array}$ & $\begin{array}{l}\text { Siswa mendengarkan penjelasan } \\
\text { dari guru. }\end{array}$ & $50 \%$ & $65 \%$ & $54,2 \%$ & $63,3 \%$ \\
\hline $\begin{array}{l}\text { (Sardiman, } \\
\text { 2010: 101). }\end{array}$ & $\begin{array}{l}\text { Siswa mendengarkan penjelasan } \\
\text { dari teman pada saat berdiskusi. }\end{array}$ & $50 \%$ & $60 \%$ & $70,8 \%$ & $72,5 \%$ \\
\hline $\begin{array}{l}\text { Writing } \\
\text { activities }\end{array}$ & $\begin{array}{l}\text { Siswa menulis hasil pemecahan } \\
\text { masalah dalam diskusi. }\end{array}$ & $50 \%$ & $65 \%$ & $80,4 \%$ & $81,3 \%$ \\
\hline $\begin{array}{l}\text { (Sardiman, } \\
\text { 2010: 101). }\end{array}$ & $\begin{array}{l}\text { Siswa menulis keterangan yang } \\
\text { diberikan guru. }\end{array}$ & $50 \%$ & $60 \%$ & $72,5 \%$ & $75 \%$ \\
\hline
\end{tabular}

Berdasarkan Tabel diatas terlihat bahwa terdapat peningkatan dari siklus I ke sisklus II, namun secara umum teleh melebihi batas yang telah ditetapkan. Berdasarkan hasil yang telah dipaparkan diatas diketahui bahwa secara keseluruhan penelitian pembelajaran model Inkuiri Terbimbing pada mata pelajaran kimia kelas XI MIA 6 SMA N 1 Singaraja tahun pelajaran 2016/2017 dikatakan telah terpenuhi yakni dapat meningkatkan kualitas proses belajar siswa pada aspek aktivitas belajar siswa serta secara tidak langsung dapat meningkatkan kualitas hasil belajar siswa yaitu hasil belajar siswa pada materi pokok laju reaksi.

\section{Penutup}

Berdasarkan hasil penelitian tindakan kelas (PTK) dapat diambil kesimpulan yaitu Penerapan model pembelajaran Inkuiri Terbimbing dapat meningkatkan aktivitas belajar siswa kelas XI MIA 6 SMA N 1 Singaraja. Peningkatan tersebut dapat dilihat pada rincian aktivitas siswa setiap katagori pada siklus I dengan kategori "Sangat Baik" sebanyak 26,67\% meningkat pada siklus II menjadi 43,33\%, kategori 'Baik" sebanyak 43.33\% meningkat pada siklus II menjadi 46,67\%, kategori "Kurang Baik" sebanyak $30,00 \%$ menurun pada siklus II menjadi 10,00\% dan kategori "Tidak Baik" tetap $0,00 \%$ pada siklus I maupun siklus II.

Secara tidak langsung peningkatan aktivitas belajar siswa berdampak pada peningkatan hasil belajar dimana rata-rata kelas hasil ulangan materi laju reaksi adalah 84 dengan ketuntasan 90\% dibandingkan rata-rata kelas hasil ulangan pada materi sebelumnya yaitu termokimia yaitu 75,1 dengan persentase ketuntasan yaitu $33,3 \%$.

\section{Daftar Pustaka}

Dahar, Ratna Wilis. 1989. Teori-teori Belajar. Jakarta: Erlangga

Mc. Taggart, R dan Kemmis, S. 1990. The Action Research Planner. Melbourne. Deakin University.

Moedjiono dan Dimyati, M. (1992/1993). Strategi Belajar Mengajar . Jakarta: Depdikbud Dirjen Pendidikan Tinggi Proyek Pembinaan Tenaga Kependidikan.

Mulyasa, H.E. 2011. Praktik Penelitian Tindakan Kelas. Bandung: PT Remaja Rosda Karya.

Purba, Michael. 2007. Kimia untuk SMA kelas XII IPA . Jakarta: Erlangga.

Ratumanan, T. G \& Laurens, T. 2003. Evaluasi hasil belajar. Semarang: Unesa University Press

Rusyan, A. (1996). Metode Pembelajaran. Jakarta : PT Amanah Duta

Sardiman, A.M. (2011). Interaksi dan Motivasi Belajar Mengajar. Jakarta: Raja Grafindo Persada

Undiksha. 2010. Buku Pedoman Studi Undiksha Tahun 2010. Singaraja: Undiksha.

Utami, Budi, Nugroho, Agung, dkk. 2009. Kimia untuk SMA/MA kelas XII IPA. Jakarta. Pusat Perbukuan. 